\title{
MINERALOGICAL COMPOSITION OF SUSPENDED PARTICLES PM10 IN THE PTOLEMAIS-KOZANI AREA, MACEDONIA, GREECE
}

\author{
Nikolaidou P. ${ }^{1,4}$, Triantafyllou A..$^{2,4}$, Kantiranis N. ${ }^{3}$ and Filippidis A. ${ }^{3}$ \\ ${ }^{1}$ Decentralized Administration of Mecedonia and Thrace, General Directorate of Environmental \\ Planning and Policy, 11 Rossidi St., 54008 Thessaloniki, Greece, p-nikola@otenet.gr \\ ${ }^{2}$ Technological Education Institution of Western Macedonia, School of Applied Science \\ Technology, Department of Environmental Engineering and Pollution Control, Koila, Kozani, \\ Greece, atria@kozani.teikoz.gr \\ ${ }^{3}$ Aristotle University of Thessaloniki, School of Geology, Department of Mineralogy-Petrology- \\ Economic Geology, 54124, Thessaloniki, Greece, kantira@geo.auth.gr,anestis@geo.auth.gr \\ ${ }^{4}$ Hellenic Open University (EAP), Postgraduate Courses Waste Management, MSc
}

\begin{abstract}
PM10 suspended particles were collected from the Kardia lignite mine (July 2009), the the campus of Technological Education Institution of Western Macedonia (December 2010) and the Kozani city centre (August 2005). The mineralogical composition and the amorphous materials content of the samples was determined by X-Ray Powder Diffraction method. All samples contain amorphous materials (43-66 $w t . \%)$, calcite (13-37 wt.\%), micas + clays (4-9 wt.\%) and quartz (2-8wt.\%), while in three samples feldspars (2-11 wt.\%) were detected. Anhydrite, which is a constituent of the fly ash and the bottom ash, was detected ( $6 \mathrm{wt} . \%)$ only in one sample from the area of Kardia mine. Gypsum was detected, in the Kardia mine (2 and 3 $w t . \%)$, in the Kozani city centre (8wt.\%) and in the University campus (13 and 14 $w t . \%)$. Gypsum is a constituent of the mined lignite, the stack-gas ash and the Saharan dust. That explains the higher concentrations of gypsum in the University campus on $1^{\text {st }}$ and $2^{\text {nd }}$ of December 2010, where the influence of Saharan dust on the atmospheric particulate matter levels in Western Macedonia was reported.

Keywords: Atmospheric pollution, Saharan dust, Lignite mining.
\end{abstract}

\section{Пєрí $\eta \psi \eta$}

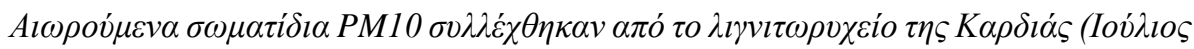

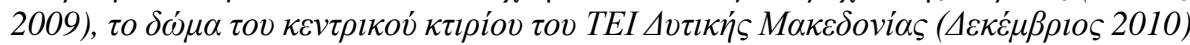

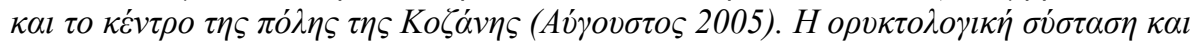

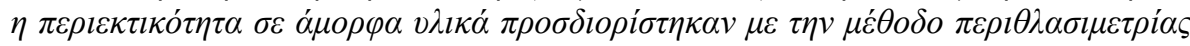

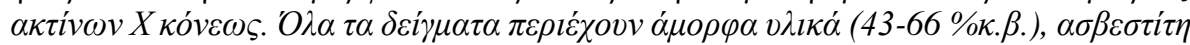

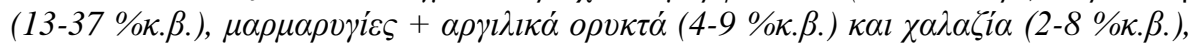

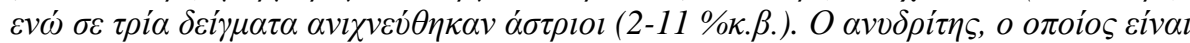

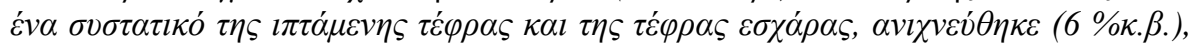

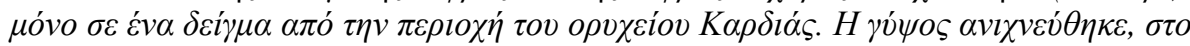

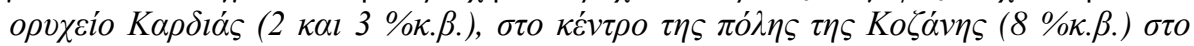

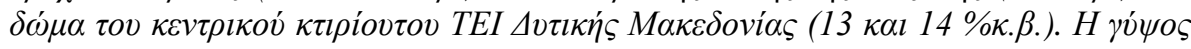




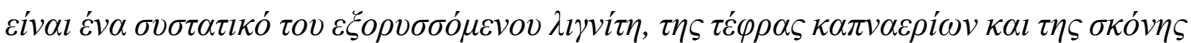

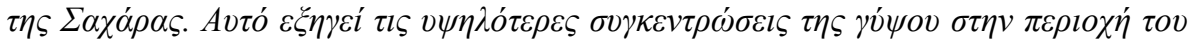

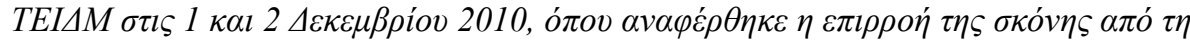

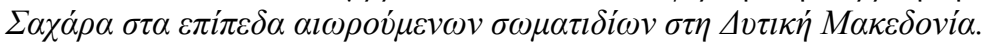

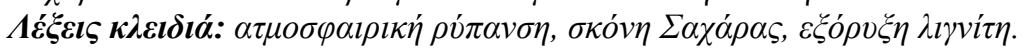

\section{Introduction}

The region of Western Macedonia constitutes an interesting and distinct case as far as air pollution is concerned. The main coal mining area in Greece is the Lignite Centre of Western Macedonia (LCWM), in the Florina-Ptolemais-Kozani area. The LCWM produces approximately 50 million tons of lignite annually to feed 6 thermal power plants, with 18 lignite thermal units and with a total installed capacity of $4388 \mathrm{MW}$. The surface lignite mining requires the excavation of about 315 million $\mathrm{m}^{3}$ of overburden and interbedded sediments per year. The surface mines occupy an area of 160000 hectares. The quality of the lignite is related both to the quality of the organic matter and to the inorganic impurities of the lignite and the nature of the thin intermediate sterile layers, which are co-excavated. Silicates, carbonates, clays, sulphates and oxides dominate the mineral matter in lignite. During lignite combustion the mineral matter of lignite undergoes a series of physical and chemical changes. Some minerals contained in the lignite ashes (fly ash, bottom ash, stack-gas ash), are initial constituents of the mined lignite, while some others are formed during the combustion of the lignite or by the soaking of the fly and bottom ashes with water during its transportation by conveyor belt from the Power Plants to the ash disposal areas (e.g., Filippidis and Georgakopoulos, 1992; Filippidis et al., 1992, 1996; Kassoli-Fournaraki et al., 1992; Kolovos et al., 2002; Kantiranis et al., 2005; Petrotou et al., 2012; Tsirambides and Filippidis, 2012; Nikolaidou, 2014).

Mineral dust is a major contributor to aerosol loading. Varied agricultural and industrial activities constitutes a subject of great interest, mainly the atmospheric burden caused by suspended particles. The problem becomes more complex if we take into consideration the contribution of the urban sources of pollution and the influence of Saharan dust on the atmospheric particulate matter levels in Southern European countries. It is estimated that million tons of desert dust are transported over the Mediterranean sea (e.g., Bergametti et al., 1989; Avila et al., 1997; Rodriguez et al., 2001; Sciare et al., 2003; Moreno et al., 2005; Gobbi et al., 2007; Viana et al., 2007; Remoundaki et al., 2011; Samoli et al., 2011). The new limits of the directive for the quality of air in Europe for PM10 is determined to $50 \mu \mathrm{g} / \mathrm{m} 3$ (Directive 2008/50/EC).

The climate of the area is generally considered to be continental with heavy rains and snowfall and many significant temperature fluctuations. Temperatures are particularly low in the winter, while the summer is cool in the mountains and hot in the plains. Humidity is lower in Kozani which lies on an extended plateau. On the part of the air temperature the coldest month is January and during the summer the hottest one is July. On the part of winds, their flow is forced to follow the topography of the area and the prevailing winds in the valley are generally either North-Northwest or SouthSoutheast (Nikolaidou, 2014).

The present paper reports on the mineralogical composition of PM10 suspended particles in the industrial axis of Western Macedonia (from north to south): Kardia lignite mine - University of Applied Sciences Western Macedonia campus - Kozani city centre.

\section{Materials and Methods}

The PM10 suspended particles were collected in teflon filters in three different places and three different periods. In the Kardia lignite mine the 2 samples were collected 17 and 31 July 2009, at the campus of Technological Education Institution of Western Macedonia the 2 samples were collected 1 and 2 December 2010 and at the Kozani city centre the 2 samples were collected 3 and 
13 August 2005. During the dates of 1 and 2 December 2010 there was influence of Saharan dust on the atmospheric particulate matter levels of Greece and Western Macedonia.

The PM10 suspended particles were selected by three different stable - portable collectors-stations, positioned in Kardia lignite mine, in the campus of Technological Education Institution of Western Macedonia and in the Kozani city centre. The conducted sampling concerns suspended particles of dust, specifically the ones called PM10 suspended particles having a diameter $<10 \mu \mathrm{m}$.

The mineralogical composition of the samples was determined by X-Ray Powder Diffraction (XRPD) method. The XRPD was performed using a Philips (PW1710) diffractometer with Nifiltered $\mathrm{CuKa}$ radiation. The randomly oriented samples were scanned over the $3-63^{\circ} 2 \theta$ interval at a scanning speed of $1.2 \% \mathrm{~min}$. The XRPD conditions were exactly the same for all samples. Semiquantitative estimates of the abundance of the mineral phases were derived from the XRPD data, using the intensity of a certain reflection, the density and the mass absorption coefficient for $\mathrm{CuKa}$ radiation for the minerals present.

In the XRPD patterns the presence of amorphous materials was clear as a broad background hump between approximately $10^{\circ}$ and $50^{\circ} 2 \theta$. The semi-quantitative estimation of the percentage of total amorphous materials was achieved by comparing the area of each broad background hump, which represented the amorphous materials in each sample, with the analogous area of standard mixtures of minerals with different contents of natural amorphous material, scanned under the same conditions. The XRPD method is a very good, effective and useful tool for the determination of the percentage of amorphous materials contained in a natural or synthetic sample (Kantiranis et al., 2004, 2005, 2006).

\section{Results}

The PM10 particles concentration and the semi-quantitative mineralogical composition of the samples are presented in Table 1. In all XRPD patterns the presence of amorphous materials was clear as a broad background hump between approximately $10^{\circ}$ and $50^{\circ} 2 \theta$, as well as the reflection of the Teflon filter (Figure 1).

\section{Discussion and Conclusions}

All samples contain amorphous materials (43-66 wt.\%), calcite (13-37 wt.\%), micas + clays (4-9 wt.\%) and quartz (2-8 wt.\%). The term "mica + clays" contains the clay minerals (kaolinite, illite, smectite, vermiculite, palygorskite) and fine micas. In five (5) samples gypsum was detected (2-14 wt.\%), in three (3) samples feldspars (2-11 wt.\%) and in one (1) sample $6 \mathrm{wt} . \%$ anhydrite.

The amorphous materials (organic and inorganic) are contained in the: a) mined lignite, b) fly ash, c) bottom ash, d) stack-gas ash and e) various industrial materials used by man (e.g., Kantiranis et al., 2004, 2005, 2006).

Concerning the minerals of Table 1: a) The fly ash and the bottom ash contain mainly the minerals anhydrite, calcite, quartz, mica + clays and feldspars, b) The stack-gas ash contains mainly calcite and gypsum, c) The mined lignite contains the minerals calcite, mica + clays, quartz, feldspars and gypsum, d) The rocks, sediments, intermediate steriles, soils and building materials of the FlorinaPtolemais-Kozani basin contain the minerals calcite, mica + clays, quartz and feldspars (e.g., Filippidis and Georgakopoulos, 1992; Filippidis et al., 1992, 1996, 1997; Kassoli-Fournaraki et al., 1992, 1993; Triantafyllou et al., 2000; Kolovos et al., 2002; Mouhtaris et al., 2003; Kantiranis et al., 2004, 2005, 2006)and e) The minerals calcite, mica + clays, quartz, feldspars and gypsum, identified as suspended particles in the Canary Islands (Spain) and the city of Volos (Greece), originate from Sahara (Africa) (e.g., Alastuey et al., 2005; Kandler et al., 2007; Coz et al., 2009; Remoundaki et al., 2011; Kantiranis et al., 2012). 


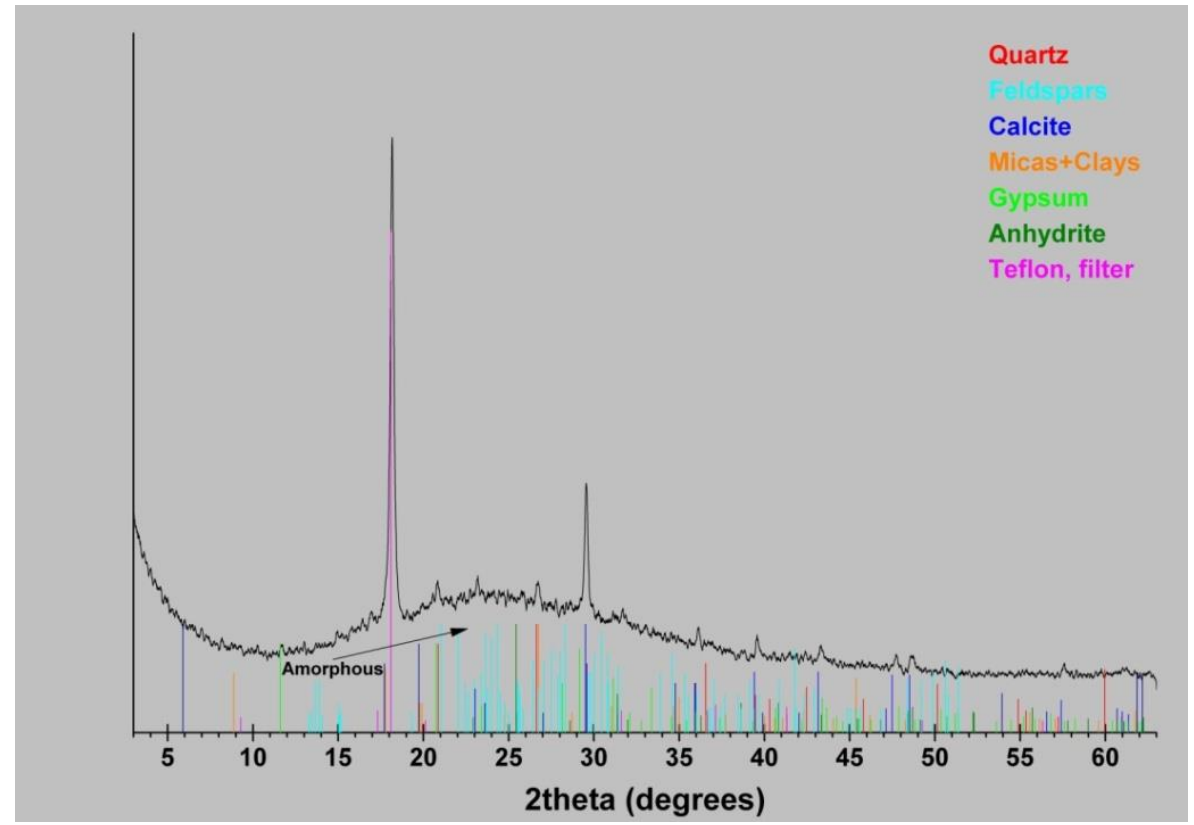

Figure 1 - X-Ray Powder Diffraction pattern of sample NP2348.

Table 1 - PM10 concentration and semi-quantitative mineralogical composition.

\begin{tabular}{|c|c|c|c|c|c|c|c|c|}
\hline $\begin{array}{l}\text { Sample No } \\
\text { Sampling date } \\
\text { Influence }\end{array}$ & $\begin{array}{l}\text { Sampling } \\
\text { Place }\end{array}$ & $\begin{array}{l}\text { Amor } \\
\text { phous } \\
\text { Wt. \% } \\
\end{array}$ & $\begin{array}{l}\text { Calcite } \\
\text { Wt. \% }\end{array}$ & $\begin{array}{c}\text { Mica+ } \\
\text { Clays } \\
\text { Wt. } \% \\
\end{array}$ & $\begin{array}{l}\text { Quartz } \\
\text { Wt.\% }\end{array}$ & $\begin{array}{c}\text { Gypsum } \\
\text { Wt. \% }\end{array}$ & $\begin{array}{c}\text { Feldsp } \\
\text { ars } \\
\text { Wt. } \%\end{array}$ & $\begin{array}{c}\text { Anhydri } \\
\text { te } \\
\text { Wt. } \% \\
\end{array}$ \\
\hline $\begin{array}{l}\text { NP2268 } \\
\text { Jul. } 17,2009\end{array}$ & \multirow{2}{*}{$\begin{array}{l}\text { Kardia } \\
\text { Lignite } \\
\text { Mine }\end{array}$} & 51 & 37 & 5 & 2 & 3 & 2 & - \\
\hline $\begin{array}{l}\text { NP2348 } \\
\text { Jul. 31, } 2009\end{array}$ & & 55 & 29 & 4 & 2 & 2 & 2 & 6 \\
\hline $\begin{array}{l}\text { NP2359 } \\
\text { Dec. 1, } 2010 \\
\text { Saharan dust }\end{array}$ & \multirow{2}{*}{$\begin{array}{l}\text { University } \\
\text { Campus }\end{array}$} & 43 & 28 & 7 & 8 & 14 & - & - \\
\hline $\begin{array}{l}\text { NP2360 } \\
\text { Dec. 2, } 2010 \\
\text { Saharan dust }\end{array}$ & & 46 & 26 & 9 & 6 & 13 & - & - \\
\hline $\begin{array}{l}\text { NP861 } \\
\text { Aug. 3, } 2005\end{array}$ & \multirow{2}{*}{$\begin{array}{c}\text { Kozani } \\
\text { City } \\
\text { Centre }\end{array}$} & 50 & 29 & 8 & 5 & 8 & - & - \\
\hline $\begin{array}{l}\text { NP876 } \\
\text { Aug. 13, } 2005\end{array}$ & & 66 & 13 & 6 & 4 & - & 11 & - \\
\hline
\end{tabular}

The possible main sources of the minerals of Table 1 are the rocks, sediments, intermediate steriles, soils, building materials, mined lignite, fly ash, bottom ash, stack-gas ash and the Saharan dust. Calcite is a constituent of all sources, quartz, mica + clays and feldspars are constituents of all sources except the stack-gas ash. Anhydrite is a constituent of the fly ash and the bottom ash, while gypsum is a constituent of the mined lignite, the stack-gas ash and the Saharan dust. These explains the mineralogical composition of the Table 1, where anhydrite was detected only in the area of Kardia mine (31 July 2009), while gypsum presents the largest concentrations (13 and 14 wt.\%) in 
the University campus on $1^{\text {st }}$ and $2^{\text {nd }}$ December 2010, where the influence of Saharan dust on the atmospheric particulate matter levels in Western Macedonia was reported.

\section{References}

Alastuey, A., Querol, X., Castillo, S., Escudero, M., Avila, A., Cuevas, E., Torres, C., Romero, P.M., Exposito, F., Garsia, O., Diaz, P., Van Dingenen, R. and Putaud, J., 2005. Characterisation of TSP and PM2.5 at Izana and St. Cruz de Tenerife (Canary Islands, Spain) during a Saharan dust episode (July 2002), Atmos. Environ., 39, 4715-4728.

Avila, A., Queralt-Mitjans, I. and Alarcon, M., 1997. Mineralogical composition of African dust delivered by red rains over northeastern Spain, J. Geophys. Res., 108, 21977-21996.

Bergametti, G., Gomez, I., Coude-Gaussen, G., Rognon, P. and Le Costumer, M.N., 1989. African dust observed over Canary Island: source regions identification and transport pattern for some summer situations, J. Geophys. Res., 94, 14855-14864.

Coz, E., Gomez-Moreno, F., Pujadas, M., Casuccio, G., Lersh, T. and Artinao, B., 2009. Individual particle characteristics of North African dust under different long-transport scenarios, Atmos. Environ., 43, 1850-1863.

Directive 2008/50/EC of the European Parliament and of the Council of 21 May 2008 on ambient air quality and cleaner air for Europe.

Filippidis, A. and Georgakopoulos, A., 1992. Mineralogical and chemical investigation of fly ash from the Main and Northern lignite fields in Ptolemais, Greece, Fuel, 71(4), 373-376.

Filippidis, A., Georgakopoulos, A. and Kassoli-Fournaraki, A., 1992. Mineralogical components from ashing at $600^{\circ} \mathrm{C}$ to $1000^{\circ} \mathrm{C}$ of the Ptolemais lignite, Greece, Trends in Mineralogy, 1 , 295-300.

Filippidis, A., Georgakopoulos, A. and Kassoli-Fournaraki, A., 1996. Mineralogical components of some thermally decomposed lignite and lignite ash from the Ptolemais basin, Greece, Intern. J. of Coal Geology, 30, 303-314.

Filippidis, A., Georgakopoulos, A., Kassoli-Fournaraki, A., Blondin, J. and Fernandez-Turiel, J.L., 1997. The sulphocalcic coal fly ashes of Ptolemais (Macedonia, Greece) and Gardanne (Provence, France), Proc. of the European Sem. on Coal Fly Ash: A Secondary Raw Material, Marseilles, France, 18 April, 149-158.

Gobbi, G.P., Barnaba, F. and Ammannato, I., 2007. Estimating the impact of Saharan dust on the year 2001 PM10 record of Rome, Italy, Atmos. Environ., 41, 261-275.

Kandler, K., Benker, N., Bundke, U., Cuevas, E., Ebert, M., Knippertz, P., Rodriguez, S., Schutz, L. and Weinbruch, S., 2007. Chemical composition and complex refractive index of Saharan minerals dust at Izana, Tenerife (Spain) derived by electron microscopy, Atmos. Environ., $41,8058-8074$.

Kantiranis, N., Georgakopoulos, A., Filippidis, A. and Drakoulis, A., 2004. Mineralogy and organic matter content of bottom ash samples from Agios Dimitrios power plant, Greece, Bull. Geol. Soc. Greece, 36(1), 320-326.

Kantiranis, N., Filippidis, A. and Georgakopoulos, A., 2005. Investigation of the uptake ability of fly ashes produced after lignite combustion, J. of Environmental Management, 76, 119-123.

Kantiranis, N., Filippidis, A., Mouhtaris, T., Paraskevopoulos, K.M., Zorba, T., Squires, C. and Charistos, D., 2006. EPI-type zeolite synthesis from Greek sulphocalcic fly ashes promoted by $\mathrm{H}_{2} \mathrm{O}_{2}$ solutions, Fuel, $85,360-366$.

Kantiranis, N., Papadopoulou, L., Zanis, P., Kollias, P. and Bourliva, A., 2012. Mineralogical, morphological and chemical characteristics of Saharan dust which fell as muddy-rain in the city of Volos (in Greek), Proc. of the $1^{s t}$ Environmental Congress of Thessaly, Skiathos, Greece, 8-10 Sept., 63-69.

Kassoli-Fournaraki, A., Georgakopoulos, A. and Filippidis, A., 1992. Heating experiments of the Ptolemais lignite in the temperature range from $100^{\circ} \mathrm{C}$ to $500^{\circ} \mathrm{C}$, Neues Jahrbuch fur Mineralogie Monatshefte, 11, 487-493. 
Kassoli-Fournaraki, A., Georgakopoulos, A., Michailidis, K. and Filippidis, A., 1993. Morphology, mineralogy and chemistry of the respirable-size $(<5 \mu \mathrm{m})$ fly ash fraction from the Main and Northern lignite fields in Ptolemais, Macedonia, Greece, Proc. of the Second Biennial SGA Meeting, Granada, Spain, 9-11 September. In: Current Research in Geology Applied to Ore Deposits, Fenoll Hach-Ali, P., Torres-Ruiz, J. and Gervilla, F., eds., La Guioconda, Granada, 727-730.

Kolovos, N., Georgakopoulos, A., Filippidis, A. and Kavouridis, C., 2002. Environmental effects of lignite and intermediate steriles coexcavation in the Southern lignite field mine of Ptolemais, Northern Greece, Energy Sources, 24(6), 561-573.

Moreno, T., Querol, X., Alastuey, A., Viana, M. and Gibbons, W., 2005. Exotic dust intrusions into the central Spain: implications for legislative controls on atmospheric particles, Atmos. Environ., 39, 6109-6120.

Mouhtaris, Th., Charistos, D., Kantiranis, N., Filippidis, A., Kassoli-Fournaraki, A. and Tsirambidis, A., 2003. GIS-type zeolite synthesis from Greek lignite sulphocalcic fly ashes promoted by $\mathrm{NaOH}$ solutions, Microporous and Mesoporous Materials, 61, 57-67.

Nikolaidou, P., 2014. Mineralogical and morphological characteristics of PM10 suspended particles in the industrial axis of Western Macedonia, MSc-thesis, Hellenic Open University, Patras, Greece, 144 pp.

Petrotou, A., Skordas, K., Papastergios, G. and Filippidis, A., 2012. Factors affecting the distribution of potentially toxic elements in surface soils around an industrialized area of northwestern Greece, Environmental Earth Sciences, 65(3), 823-833.

Remoundaki, E., Bourliva, A., Kokkalis, P., Mamouri, R.E., Papayannis, A., Grigoratos, T., Samara, C. and Tsezos, M., 2011. PM10 Composition during an intense Saharan dust transport event over Athens (Greece), Sci. Total Environ., 409, 4361-4372.

Rodriquez, S., Querol, X., Alastuey, A., Kallos, G. and Kakaliagou, O., 2001. Saharan dust contribution to PM10 and TSP levels in southeastern and eastern Spain, Atmos. Environ., 35, 2433-2447.

Samoli, E., Kougea, E., Kassomenos, P., Analitis, A. and Katsouyanni, K., 2011. Does the presence of desert dust modify the effect of PM10 on mortality in Athens, Greece? Sci. Total Environ., 409(11), 2049-2054.

Sciare, J., Bardouki, H., Moulin, C. and Mihalopoulos, N., 2003. Aerosol sources and their chemical contribution to the chemical composition of aerosols in the Eastern Mediterranean Sea during summertime, Atmos. Chem. Phys., 3, 291-302.

Triantafyllou, A., Filippidis, A., Patra, A., Pavlidis, A. and Kantiranis, N., 2000. Concentrations, mineralogy and morphology of the suspended particles PM10 in the city of Kozani (in Greek with English abstract), Proc. of the $1^{\text {st }}$ Congress of the Economic Geology, Mineralogy and Geochemistry Committee of the Geological Society of Greece, Kozani, Greece, 12-13 Feb., 452-462.

Tsirambides, A. and Filippidis, A., 2012. Energy mineral resources of Greece, J. of Environmental Science and Engineering, B1, 709-719.

Viana, M., Maenhaut, W., Chi, X., Querol, X. and Alastuey, A., 2007. Comparative chemical mass closure of fine and coarse aerosols at two sites in south and west Europe: implications for EU air pollution policies, Atmos. Environ., 39, 5865-5875. 